NBER WORKING PAPER SERIES

\title{
MATERNITY AND FAMILY LEAVE POLICY
}

Maya Rossin-Slater

Working Paper 23069

http://www.nber.org/papers/w23069

\author{
NATIONAL BUREAU OF ECONOMIC RESEARCH \\ 1050 Massachusetts Avenue \\ Cambridge, MA 02138 \\ January 2017
}

Prepared for inclusion in the Oxford Handbook on the Economics of Women, ed. Susan L. Averett, Laura M. Argys and Saul D. Hoffman. (New York: Oxford University Press. Forthcoming, 2018). I am grateful to Shelly Lundberg, Jane Waldfogel, and the handbook editors for helpful comments. I thank Nicole Iannaccone for excellent research assistance. The views expressed herein are those of the author and do not necessarily reflect the views of the National Bureau of Economic Research.

NBER working papers are circulated for discussion and comment purposes. They have not been peer-reviewed or been subject to the review by the NBER Board of Directors that accompanies official NBER publications.

(C) 2017 by Maya Rossin-Slater. All rights reserved. Short sections of text, not to exceed two paragraphs, may be quoted without explicit permission provided that full credit, including (C) notice, is given to the source. 
Maternity and Family Leave Policy

Maya Rossin-Slater

NBER Working Paper No. 23069

January 2017, Revised January 2017

JEL No. H4,J08,J13,J16,J78

\begin{abstract}
$\underline{\text { ABSTRACT }}$
Maternity and family leave policies enable mothers to take time off work to prepare for and recover from childbirth and to care for their new children. While there is substantial variation in the details of these policies around the world, the existing research yields the following general conclusions. First, despite important barriers to the take-up of leave, both the implementation of new programs and extensions of existing ones increase leave-taking rates among new parents. Second, leave entitlements less than one year in length can improve job continuity for women and increase their employment rates several years after childbirth; longer leaves can negatively influence women's earnings, employment, and career advancement. Third, extensions in existing paid leave policies have no impact on measures of child well-being, but the introduction of short paid and unpaid leave programs can improve children's short- and long-term outcomes. Fourth, while more research is needed, the current evidence shows minimal impacts of existing U.S. state-level programs on employer-level outcomes such as employee productivity, morale, profitability, turnover rates, or the total wage bill.
\end{abstract}

Maya Rossin-Slater

Department of Economics

University of California, Santa Barbara

2127 North Hall

Santa Barbara, CA 93106

and NBER

maya.rossin-slater@ucsb.edu 


\section{Introduction}

In most developed countries today, the majority of mothers with infants under the age of one participate in the labor force. ${ }^{1}$ Maternity and family leave policies are designed to provide time off from work so that new mothers can prepare for and recover from childbirth, parents can care for their newborn or newly adopted children, and individuals can care for seriously ill family members. These policies aim to help workers balance competing job and family responsibilities, with the goal of improving family well-being and promoting career continuity. Moreover, since women typically do a larger share of family and child care than men, these policies may also impact gender inequality both in the labor market and in the home. $^{2}$

The vast majority of countries around the world guarantee some type of paid maternity leave to new working mothers. Most developed countries also provide access to other types of leave: (i) paternity (i.e., leave designated specifically for new fathers), parental (i.e., leave that can be taken by both new mothers and fathers), or family (i.e., leave that can be taken to care for ill family members in addition to new children). These policies vary substantially in several key features: the duration of leave provided, benefit amounts and structure, the presence (or absence) of job protection, financing, coverage, and eligibility. The United States is an outlier in this policy setting as it is one of only two countries in the world without a statutory national paid maternity leave policy (the other country is Papua New Guinea). Additionally, unlike most high-income countries, the U.S. does not guarantee any paid paternity, parental, or family leave to its workers at the national level. ${ }^{3}$

The substantial degree of variation in maternity and family leave policies around the globe

\footnotetext{
${ }^{1}$ According to the Bureau of Labor Statistics, the labor force participation rate of American mothers with infants under age one was 58.1 percent in 2015. See: http://www.bls.gov/news.release/famee.nr0.htm. For recent statistics on labor force participation rates of mothers of young children in other OECD countries, see Chart LMF1.2.B here: http://www.oecd.org/els/family/LMF1_2_Maternal_Employment_Sep2014. pdf.

${ }^{2}$ For recent data on gender differences in child care, see: http://www.pewsocialtrends.org/2013/03/ 14/modern-parenthood-roles-of-moms-and-dads-converge-as-they-balance-work-and-family/.

${ }^{3}$ The information about the current policy landscape around the world is from Addati et al. (2014).
} 
raises questions about their impacts on women's labor market trajectories, child welfare, and employers. The effects on women's labor supply are potentially ambiguous, as they depend on whether these policies encourage women who would have otherwise quit working to stay in the labor market or instead increase women's time away from work among those who would have kept working anyway. Child welfare may be impacted through a number of channels, including a reduction in maternal stress during and immediately after pregnancy, changes to the quantity and quality of time that a parent spends with his/her newborn child, and changes to family income. Finally, the impacts on employers are also uncertain. Even if employers do not face direct costs of financing paid leave (as many current policies are financed through employee payroll taxes or public funds), they might encounter other challenges due to having to hire temporary replacement workers or coordinating the schedules of their employees. Alternatively, employers may experience benefits as a result of these policies, if workers who would have otherwise quit instead return to their jobs and thus reduce overall turnover rates.

This chapter first describes the current policy landscape around the world and within the United States, and then discusses the evidence on the following issues related to maternity and family leave: (i) take-up of leave, (ii) impacts on women's labor market outcomes, (iii) impacts on child outcomes, and (iv) impacts on employer outcomes.

As the research on several of these topics is extensive, I follow certain selection criteria to choose what to cover in this chapter. I focus on studies that analyze the impacts of maternity and family leave on new parents and their children; I do not discuss the evidence on the impacts of leave taken to care for ill family members. This restriction stems from a lack of existing rigorous research that focuses on caregivers using family leave to care for ill family members rather than children.

Further, I review the research on the impacts of leave policies on women's labor market outcomes, but do not cover in detail the evidence on men's leave-taking and labor market trajectories. Although male participation in family leave has become increasingly important 
due to changing gender norms and the implementation of leave policies specifically targeting new fathers (e.g., "daddy quotas" or "daddy months" in countries such as Canada and Sweden), this chapter focuses on women's role in the economy. ${ }^{4}$

I also limit my review to studies on policies in developed countries. Female and maternal labor force participation rates are lower in most developing countries than in higher income countries, making access to maternity and family leave less salient for many women in the developing world. ${ }^{5}$ As such, nearly all of the existing evidence on these policies comes from developed countries, mostly in North America and Europe.

Additionally, I constrain my review to policies that have been evaluated in the academic literature using empirical designs that allow for causal inference. This is a particularly important issue because individuals who have access to maternity and/or family leave are not randomly selected. For instance, in the United States, higher wage workers are much more likely to have access to employer-provided paid family leave than their lower-earning counterparts (Gault et al., 2014). As such, simply comparing the outcomes of workers who are covered by family leave to those of workers who are not makes it difficult to isolate the causal effects of leave policies from the consequences of other individual or family background characteristics. Therefore, I limit the review to policies that have been studied using empirical methods that attempt to control for non-random selection into policy treatment.

Finally, I mostly restrict the review of the literature to articles and reports published in the last two decades (since 1996), as well as recent working papers that have not yet been published.

My review of the research on maternity and family leave policies yields the following key take-away points. First, despite important barriers to the take-up of leave (including a lack of awareness of existing policies, stringent eligibility requirements, low or no pay, and the

\footnotetext{
${ }^{4}$ For recent evidence on paternity leave, paternal involvement in childcare, and fathers' labor market outcomes, see: Tanaka and Waldfogel (2007); Nepomnyaschy and Waldfogel (2007); Rege and Solli (2013); Huerta et al. (2013); Dahl et al. (2014); Almqvist and Duvander (2014); Cools et al. (2015); Bartel et al. (2015); Bünning (2015); Bunning and Pollmann-Schult (2016).

${ }^{5}$ For information on female labor force participation in developing countries, see: https://www.imf .org/ external/pubs/ft/sdn/2013/sdn1310.pdf.
} 
absence of job protection), both the implementation of new programs and extensions of existing ones increase leave-taking rates among mothers and fathers around the world. Second, leave entitlements less than one year in length can improve job continuity for women and increase their employment rates several years after childbirth. However, longer leaves can have negative effects on women's earnings, employment, and career advancement. Third, extensions in existing paid leave policies have no impact on a variety of measures of child well-being, but the introduction of short paid and unpaid leave programs can improve children's short- and long-term outcomes. Fourth, while more research needs to be done on employers, the current evidence shows minimal impacts of existing U.S. state-level programs on outcomes such as employee productivity and overall profitability.

The rest of the chapter unfolds as follows. Section 2 provides more details on maternity and family leave policies around the world and within the United States. Section 3 discusses the research on the take-up of these policies. Section 4 reviews the evidence on the impacts of leave policies on women's labor market outcomes. Section 5 covers the research on the consequences of leave policies on families and children. Section 6 describes the studies on employer outcomes. Section 7 offers concluding thoughts and avenues for future research.

\section{Maternity and Family Leave Policy Landscape}

\subsection{Global Comparisons}

The International Labour Organization (ILO) of the United Nations - the central global agency dedicated to labor and family issues - considers maternity protection a fundamental human right. The ILO's primary goals with regard to maternity protection are: (1) to enable women to combine their reproductive and productive roles successfully; (2) to prevent unequal treatment at work due to their reproductive role; and (3) to promote equal opportunities and treatment in employment and occupation, without prejudice to health or economic security (Addati et al., 2014, p.1-2). Maternity and family leave policies are central 
components of international efforts to meet these goals.

While nearly all countries in the world have some type of statutory maternity leave policy, there is wide variation in four key policy levers: duration, rights to payment during leave, job protection entitlement, and the financing of benefits. Additionally, there are differences in whether countries offer paternity, parental, or family leave more generally. I discuss these factors here. ${ }^{6}$

Duration of maternity leave. Since 2000, the ILO standard for duration of maternity leave has been 14 weeks (the previous standard was 12 weeks). Globally, 98 out of 185 countries with available data meet or exceed this standard. Out of them, 42 countries provide 18 weeks or more. Sixty countries provide 12 or 13 weeks, while 27 countries provide less than 12 weeks of leave.

Payment during maternity leave. The ILO also sets a standard on payments during leave. The idea is that the benefit should allow a new mother to "maintain herself and her child in proper conditions of health and with a suitable standard of living" (Addati et al., 2014, p. 16). As such, the ILO recommends that the cash benefits paid to women during maternity leave should amount to at least two-thirds of their previous earnings.

As noted above, only two countries in the world-Papua New Guinea and the United States - have no legal provision for cash benefits during maternity leave. The remainder offers some sort of pay, but varies dramatically in terms of payment structure and duration. The most common method is to calculate benefits based on a woman's previous earnings, and then pay a constant benefit throughout the duration of leave. But there are some countries (e.g.: Canada, Iran, Ireland, Jamaica, Haiti, Malta, Swaziland, and the United Kingdom) where the benefit is only paid for part of the leave, while the rest of the leave duration is unpaid. In a few countries (e.g.: Albania and Thailand), the amount paid at the beginning of the leave period is higher than the amount paid at the end. In still other countries (e.g.: Lesotho and

\footnotetext{
${ }^{6}$ Unless otherwise noted, the information in this section is from Addati et al. (2014).
} 
Zambia), only workers in certain industries or occupations are guaranteed payment during leave. Moreover, there are quite a few countries where the benefit structure is non-linear: workers receive a percentage of their previous earnings, up to a maximum. This practice exists in a number of middle- and high-income countries, including Belgium, Chile, France, Israel, the Netherlands, New Zealand, Russia, and Switzerland. Finally, several countries (e.g.: Australia, Germany, and Seychelles) offer a flat maternity benefit that is not indexed to a woman's prior earnings.

According to an analysis by the ILO, 74 out of 167 countries with available data provide maternity benefits that amount to at least two-thirds of a woman's previous earnings for at least 14 weeks. Out of them, 61 countries provide 100 percent of prior earnings for 14 weeks.

Job protection during maternity leave. The current ILO standard prohibits discrimination in employment before, during, and immediately after the maternity leave period. The right to return to one's pre-leave employer (i.e., job protection) should therefore be implicit in the entitlement to maternity leave. However, out of 146 countries with available information, 82 do not guarantee job protection during maternity leave.

Financing maternity leave benefits. The ILO recommends that employers should not bear a direct burden of financing maternity leave. Instead, benefits should be provided through compulsory social insurance or public funds. This recommendation is based in an effort to combat potential discrimination against women in the labor market, which may be more likely if employers face direct costs of women taking leave.

There is variation in the sources of funding for maternity benefits around the world. Most countries (107 out of 185 with available data) finance maternity leave benefits through an employment-related social insurance system, to which employees (and rarely employers) pay into. In some countries (47 out of 185), employers pay benefits directly. Less commonly (in 4 countries-Australia, Georgia, New Zealand, and the United Kingdom), maternity benefits are paid directly out of public funds. The remaining countries have mixed funding schemes. 
Other kinds of leave. Out of 167 countries with available data, 79 have a paternity leave entitlement in their legislation. Paternity leave is typically much shorter than maternity leave - ranging from one day (in Tunisia) to 90 days (in Iceland and Slovenia). However, in the vast majority of countries with paternity leave (71 out of the 79 countries), this leave is paid, usually at a rate of 100 percent of previous earnings.

Parental leave is relatively long-term leave that is typically available to either or both parents (although some countries have dedicated non-transferrable portions specifically for fathers), and is meant to allow them to care for an infant or young child after the end of the maternity or paternity leave period. Overall, 66 out of 169 countries with available data have a parental leave provision; nearly all of them are in the developed world. Out of these 66 countries, 36 offer cash benefits during the leave, while the rest offer only unpaid parental leave. In the countries with paid parental leave, the benefits are usually lower than those associated with maternity or paternity leave.

Finally, while most of the discussion here is centered on leave programs available for new parents, there are countries - including the United States - where maternity, paternity, and parental leaves are integrated with a broader family leave system. In these settings, employees are entitled to take leave for the purpose of caring for a severely ill family member. In general, however, caregiving leave is less common than leave for new parents. For example, while nearly all OECD countries offer parental leave, only two-thirds have any leave available to caregivers (Colombo et al., 2011).

\subsection{The United States}

Since the United States is an outlier in terms of maternity and family leave provision, it is useful to describe the U.S. policy setting in more detail. Currently, the only national policy is the Family and Medical Leave Act (FMLA), which was enacted in $1993 .{ }^{7}$ The

\footnotetext{
${ }^{7}$ Prior to 1993, twenty-five states and the District of Columbia had some type of family leave provisions, which were mostly unpaid and did not offer job protection, and varied in length between six and sixteen weeks (Trzcinski and Alpert, 1994).
} 
FMLA mandated that employers grant 12 weeks of unpaid job-protected family leave with continued coverage by the employer's health insurance (if such coverage was already offered at the job) to qualifying workers. To be eligible, workers have to have worked at least 1,250 hours in the preceding year for an employer with at least 50 employees (within a 75 mile radius of the employment location). As a result of these firm size and work history requirements, only slightly more than half of U.S. workers in the private sector were eligible for FMLA at the time of its inception (Ruhm, 1997). According to most recent data from 2012, a little less than 60 percent of American private sector workers are eligible for the FMLA currently (Klerman et al., 2012).

Access to paid leave is very limited in the U.S. As of 2015, only 12 percent of private sector workers had access to paid family leave through their employers. ${ }^{8}$ In five states (California, Hawaii, New Jersey, New York, and Rhode Island) birth mothers qualify for around 6 weeks of paid leave under the temporary disability insurance (TDI) system. This leave has been available to pregnant women and new mothers since the 1978 Pregnancy Discrimination Act, which mandated that states with existing TDI programs allow women to take leave to prepare for and recover from childbirth.

Additionally, three states have enacted paid family leave (PFL) programs: California (in 2004), New Jersey (in 2008), and Rhode Island (in 2014). New York passed a PFL policy that will go into effect in 2018. As shown in Figure 1, there is some variation in the duration of paid leave across states - from 4 weeks in Rhode Island to 12 weeks in New York. In all states, benefits are paid as a percentage of prior earnings, up to a ceiling. Figure 2 depicts the average weekly benefit in 2015 for the three states with existing programs. ${ }^{9}$ The leaves offered in California and New Jersey are not job protected (although workers may qualify for job protection under the federal FMLA), while leaves in Rhode Island and New York are. Finally, paid family and medical leave has been a part of the national discussion in recent

\footnotetext{
${ }^{8}$ See: https://www.dol.gov/wb/PaidLeave/PaidLeave.htm.

${ }^{9}$ In New York, when the program is fully implemented in 2021 , the benefit will be set at $67 \%$ of an employee's average weekly wage, capped at $67 \%$ of the statewide average weekly wage. See: https://www . ny.gov/programs/paid-family-leave-strong-families-strong-ny for more information.
} 
years as well. As such, understanding the consequences of these types of policies on workers, families, and employers is timely and relevant.

\section{Take-Up of Leave}

Before discussing the impacts of maternity and family leave policies on women's labor market outcomes, child well-being, and employers, it is important to understand how these programs affect the first-order outcome of leave-taking. A variety of constraints and barriers may limit the take-up of leave among employees.

One possible barrier to take-up is a lack of awareness of existing policies. For instance, a recent field poll by the California Center for Research on Women and Families found that only 36 percent of voters were aware of California's PFL program in 2015, 11 years after the program went into effect (DiCamillo and Field, 2015). Stringent eligibility requirements, low (or a lack of) pay, and the absence of job protection may also prohibit workers from taking up leave, especially those who are in low-wage jobs (Fass, 2009).

Nevertheless, a large body of research suggests that the implementation of new maternity and family leave policies and extensions in existing policies do in fact increase leave-taking rates. U.S. studies have used difference-in-difference research designs to study the impacts of FMLA by comparing outcomes in states that had existing leave policies to those in states without any leave policies, before and after the law went into effect. Waldfogel (1999) finds that the introduction of FMLA increased leave-taking by about 23 percent among mothers of children under age one (Waldfogel, 1999). Examining the timing of leave-taking more closely, Han et al. (2009) find that the FMLA and state-level maternity leave policies increase maternal leave-taking by 13 percent during the birth month, 16 percent during the month after birth, and a marginally significant 20 percent during the second month after birth. ${ }^{10}$

\footnotetext{
${ }^{10}$ Studies on the earlier state-level unpaid leave policies - which use variation in the timing of implementation in difference-in-difference designs - have also shown that they are associated with increased leave-taking among mothers, although these effects are smaller and the estimates are less consistent (Klerman and Lei-
} 
The enactment of California's PFL (CA-PFL) program in 2004 has spurred a new and growing literature to study its impacts. These studies use difference-in-difference as well as triple-difference empirical designs, comparing individuals with infants to individuals with older children, in California versus in other states, before and after the law went into effect. ${ }^{11}$ By comparing changes in outcomes in California to those in other states, these studies are able to account for overall time trends in leave-taking rates (e.g., due to the Great Recession) as well as for any time-invariant state-specific factors (e.g., the impacts of state-specific political "culture" or any other policies or demographics that do not change over the time period analyzed). Triple-difference models, which include a third control group consisting of individuals with older children, are further equipped to account for potential differential time trends in outcomes across states (e.g., if the Great Recession affected people in California differently from those in other states).

Rossin-Slater et al. (2013) show that the policy nearly doubled leave-taking rates among mothers of children under one year old, relative to control groups of similar mothers in other states and mothers of slightly older children in California. Moreover, they find evidence that the impacts on leave-taking are largest for the least advantaged mothers (those who are unmarried, minorities, and with low education levels), suggesting that access to governmentprovided paid leave may reduce disparities in leave usage. Baum and Ruhm (2016) study both mothers' and fathers' leave-taking, finding that CA-PFL increased leave duration by approximately five weeks for mothers and by less than one week for fathers. Bartel et al. (2015) use a larger data set to examine leave take-up among fathers, as well as leave-sharing in dual-earner households, finding that CA-PFL implementation led to an increase in the likelihood of being on leave during the survey week of about 0.9 percentage points (or, 46 percent relative to the pre-treatment mean) for fathers of infants. They show that in households where both parents work, CA-PFL increased both father-only leave-taking (i.e., bowitz, 1997; Han and Waldfogel, 2003; Washbrook et al., 2011).

${ }^{11}$ Eligibility for CA-PFL is limited to the first year after the birth or adoption of a new child; as such, parents of children older than one can serve as a control group. 
father on leave while mother is at work) and joint leave-taking (i.e., both parents on leave at the same time) in about equal proportions.

In other countries, there is a wealth of evidence on the impacts of paid leave policies on leave-taking. For example, Baker and Milligan (2008a) and Baker and Milligan (2010) show that a Canadian expansion in paid job-protected parental leave from six months to one year led to about a three month increase in leave duration among new mothers. In Austria, Lalive and Zweimüller (2009) study a reform that increased the duration of parental leave from one to two years, finding a ten month increase in leave duration among mothers in the second year after childbirth. In Norway, the introduction of a policy that granted four months of paid leave to new mothers (on top of an existing period of unpaid leave) led to an increase in leave take-up of about four months (Carneiro et al., 2015). ${ }^{12}$

\section{Impacts on Women's Labor Market Outcomes}

While family and maternity leave policies are expected to increase leave-taking, their impacts on workers' subsequent labor market outcomes such as employment and wages are theoretically ambiguous (Klerman and Leibowitz, 1994). Following the birth of a child, an employed woman has three choices: she can continue working without taking leave, she can take leave and return to her job after, or she can quit her job. Maternity and family leave policies are likely to increase leave-taking, but this effect may come from two groups of women: (i) those who would have otherwise remained employed and on the job, and (ii) those who would have otherwise quit their jobs. For women in the first group, the leave policy will likely increase time away from the job, but will have no impact on their short-run employment as they would have remained employed anyway. For women in the second group, the leave policy may increase short-run employment, as some of them may choose to stay employed and take

\footnotetext{
${ }^{12}$ See, also: Ruhm (1998) for evidence from 16 European countries; Patnaik (2016) for evidence on fathers in Canada; Liu and Skans (2010) and Ekberg et al. (2013) for evidence from Sweden; Dustmann and Schönberg (2012) and Schönberg and Ludsteck (2014) for evidence from Germany; and Dahl et al. (2016) for additional evidence from Norway.
} 
leave instead of quitting their jobs.

Moreover, there may be consequences for labor market outcomes in the medium- and long-term as well. A large body of research has documented a persistent "motherhood wage penalty" that can last 10 to 20 years after childbirth - mothers earn lower wages, work fewer hours, and are less likely to be employed than fathers or childless women and men (see, e.g.: Waldfogel, 1998; Lundberg and Rose, 2000; Blau and Kahn, 2000; Anderson et al., 2002; Kleven et al., 2016). Leave policies may help ameliorate some of the negative labor market consequences of childbearing that are disproportionately borne by women. In particular, women who are induced to take leave and remain employed instead of quitting may experience greater job continuity, which may improve their labor market prospects in the future. But, there may be negative impacts on later employment and earnings for women who spend a longer period of time away from work as a result of the leave policy. Additionally, employers who find leave-taking costly may discriminate against female employees by being less likely to hire them or by offering them lower wages.

Clearly, the impacts of leave policies on women's labor market outcomes depend on a number of factors, including the length of leave provided, whether the leave is paid or unpaid, and whether there is job protection. A large literature has studied these issues both in the U.S. and in other countries.

In general, short unpaid leave policies enable women who can afford to take leave to return to employment after childbirth, but have minimal impacts on their subsequent labor market outcomes. Using a difference-in-difference design, Baum (2003) shows that U.S. state maternity leave policies and the FMLA have increased the probability that eligible mothers return to their pre-childbirth jobs by about 30 percent. However, there are no significant impacts of FMLA on women's employment or wages in the years after the policy went into effect (Waldfogel, 1999; Han et al., 2009). ${ }^{13}$

Cross-country comparisons that use variation in the length of leave provision across coun-

\footnotetext{
${ }^{13}$ There is some evidence that the FMLA led to an increase in part-time work for women (Schott, 2012).
} 
tries and over time show that paid maternity and family leave provisions of up to one year in length typically increase the likelihood of employment shortly after childbirth, and have either positive or zero impacts on women's medium- and long-run employment and earnings; longer paid leave entitlements can negatively affect women's long-term wages (Ruhm, 1998). However, causal inference from these types of analyses can be difficult, as trends in other country-specific factors (e.g., economic conditions or the implementation of other policies such as public childcare) may be correlated with both the length of leave and women's labor market outcomes.

To address this challenge, a number of studies have focused on one country at a time, examining the impacts of extensions in existing family and maternity leave policies. These research designs allow for more credible causal identification, as they compare the outcomes of women who have children born under more generous leave policies to those of similar women with children born under less generous leave regimes. The evidence from these studies is generally consistent with the conclusions from cross-country comparisons.

For example, Baker and Milligan (2008a) examine several extensions in job-protected maternity leave of up to one year in length in Canada, finding a 22 percent increase in the likelihood that women return to their pre-childbirth employers, and either positive or zero effects on employment overall. In Germany, the implementation of a one-year paid leave policy led to a 12 percent increase in mothers' employment probability after the end of the benefit period (Kluve et al., 2013), and positive impacts on employment three to five years after childbirth for women with relatively high levels of education (Bergemann and Riphahn, 2015). However, another study from Germany finds that longer periods of leave at lower or no pay can have adverse impacts on women's wages up to eight years after their return to work (Schönberg and Ludsteck, 2014). Similarly, a study from France finds that an extension of three years of paid leave to families with two children led to lower wages for mothers up to ten years later (Lequien, 2012). In Austria, an extension of paid leave from one to two years reduced mothers' earnings in the short-term, but had no longer-term impacts (Lalive 
and Zweimüller, 2009). In Norway, Dahl et al. (2016) find no significant impacts of a variety of extensions in paid maternity leave from four to eight months on either earnings or labor force participation among mothers.

In the U.S., a handful of studies has examined the labor market consequences of California's first-in-the-nation paid leave policy, which provides a relatively short amount of leave (six weeks). Rossin-Slater et al. (2013) show that CA-PFL implementation increased the weekly work hours of employed mothers of one to three year-old children by 10 to 17 percent. Baum and Ruhm (2016) find that CA-PFL raised employment probabilities of mothers by about 23 percent one year afer childbirth, and increased hours and weeks of work during the child's second year of life by 18 and 11 percent, respectively. However, when studying all young women in California (and not just mothers), Das and Polachek (2015) find some evidence that CA-PFL led to higher labor force participation rates, unemployment rates, and unemployment duration in the years after implementation.

As noted in Section 2, CA-PFL does not offer job protection. A recent study by Stearns (2016) demonstrates that job protection during leave can have a separate (and bigger) impact on women's employment relative to wage replacement alone. She examines two reforms in Great Britain, and separately identifies the impacts of expanding access to paid leave from the effects of job protection during leave. She finds that while access to paid maternity leave increases the probability of returning to work in the short-run, there is no effect on long-run employment. By contrast, making job protection available to new mothers results in large increases in maternal employment rates and job tenure five years after childbirth. However, by increasing time away from work, the job protection reform has negative consequences of other measures of career success such as promotions to managerial positions. This study suggests caution in endorsements of maternity leave policies as tools for reducing long-run gender inequality in the labor market. ${ }^{14}$

In sum, maternity and family leave entitlements less than one year in length tend to

\footnotetext{
${ }^{14}$ Another study from Britain has found that paid maternity leave has large impacts on short-term employment rates of married women (Gregg et al., 2007).
} 
increase job continuity by allowing women to return to work at the end of the leave period, and - especially if the leave is paid and job-protected - can increase women's employment rates several years later. However, longer leaves can have negative impacts on women's long-term wages, employment, and career advancement.

\section{Impacts on Children}

Helping families (and children in particular) is a central goal of maternity and family leave policies. There are a number of channels through which children may be impacted. First, the guarantee of leave (especially if it is job-protected) may lower maternal stress during pregnancy, which has been shown to adversely affect child well-being at birth and in later life (see, e.g.: Currie and Rossin-Slater, 2013; Black et al., 2016; Aizer et al., 2016; Persson and Rossin-Slater, 2016). Second, leave can increase the amount of time a child spends with his mother shortly after birth. As a result, a mother may be better able to breastfeed, care for her child when he gets sick, and to seek prompt medical care if necessary. Third, depending on whether or not the leave is paid and the benefit amount, there may be impacts on family income and the family's material resources available for child rearing.

Most of the evidence on the impacts of leave policies on families and children comes from countries outside the U.S. Cross-country comparisons suggest that longer leave policies are correlated with lower infant and child mortality rates (Ruhm, 2000; Tanaka, 2005; Heymann et al., 2011). As with similar studies considering women's labor market outcomes, causal inference can be challenging due to differential country-specific trends in child health.

Studies that address the issue of endogeneity by examining reforms of paid leave policies in one country at a time generally find little evidence of improved child well-being. For instance, in Canada, an extension of paid maternity leave from six to twelve months increased maternal time at home and breastfeeding rates, but had no impacts on indicators of children's cognitive or behavioral development in early childhood (Baker and Milligan, 2008b, 2010, 2015). A Swedish study examines an extension of paid leave from twelve to fifteen months 
in 1988, finding no impacts on children's cognitive outcomes at age sixteen (Liu and Skans, 2010). In Denmark, a reform that extended paid leave from 14 to 20 weeks in 1984 led to no effects on children's educational attainment (Rasmussen, 2010). An Austrian extension in paid leave from 12 to 24 months in 1990 had no effects on age-15 test scores on average (Danzer and Lavy, 2016). In Germany, Dustmann and Schönberg (2012) study three reforms: an extension in paid leave from two to six months (in 1979), an extension in paid leave from six to ten months (in 1986), and an extension in unpaid leave from 18 to 36 months (in 1992). They find no long-term effects on children's educational attainment or earnings at age 28. In Norway, a series of extensions in paid maternity leave from four to eight months over 1987-1992 had no impacts on children's schooling outcomes (Dahl et al., 2016).

However, this type of research can offer little guidance on what to expect from the introduction (rather than extension) of a shorter paid maternity or family leave program. Additionally, the institutional setting where a leave policy is enacted likely matters - a reform expanding paid leave from twelve to fifteen months in a setting with subsidized child care and universal health insurance (e.g., as is the case in Sweden) is dramatically different from one that provides six weeks of paid leave for the first time in a setting where neither child care nor health insurance is guaranteed (e.g., as is the case with California's program). As such, it is perhaps not surprising that a recent study from Norway on the introduction (rather than extension) of a four-month paid maternity leave policy, where the previous policy only granted three months of unpaid leave, contrasts with the other findings from Europe and Canada. Carneiro et al. (2015) find that the implementation of the Norwegian policy led to a two percentage point decline in high school drop-out rates and a five percent increase in earnings at age 30, with impacts concentrated among children from disadvantaged backgrounds.

Moreover, evidence from the U.S. suggests that even the introduction of twelve weeks of unpaid leave can improve child health. Rossin (2011) studies the impacts of the FMLA using a triple-difference design, comparing the health outcomes of children born in states without 
pre-FMLA leave policies to those of children born in states with existing leave policies, in counties with large versus small shares of firms with at least 50 employees, before and after the law went into effect. She finds that the implementation of FMLA led to a small six gram increase in average birth weight, and a fairly large ten percent reduction in the infant mortality rate. These health impacts are present only for children of highly educated and married mothers, who were most likely to be eligible for FMLA and able to afford to take unpaid time off.

With regard to U.S. evidence on paid leave, Stearns (2015) examines the consequences of the introduction of about six weeks of paid maternity leave through the TDI system. The results show that TDI coverage of paid maternity leave lowered rates of low birth weight (less than 2,500 grams) and pre-term births (less than 37 weeks gestation) by five and eight percent, respectively. Unlike Rossin (2011)'s study, these impacts were largest among disadvantaged African-American and unmarried mothers, implying that paid and unpaid leave policies effectively target different populations. Finally, recent evidence also shows that California's PFL program increased breastfeeding rates by ten to twenty percentage points three, six, and nine months after the birth of a child (Huang and Yang, 2015). However, there is currently no published research on the causal impacts of CA-PFL on other measures of child health or well-being.

In sum, while extensions in existing paid leave policies have had little impact on children's well-being, the evidence suggests that the introduction of short paid and unpaid leave programs can improve children's short and long-term outcomes.

\section{Impacts on Employer Outcomes}

As discussed in Section 2, many existing paid leave programs are financed entirely through employee payroll taxes, meaning that there are no direct costs to employers in terms of funding the leave. Yet employers whose workers take leave might face other costs as a result of having to hire replacement workers or coordinating the schedules of existing employees. 
Employers may also experience benefits, if workers who would have otherwise quit instead return to their jobs and reduce turnover rates.

The existing literature on the impacts of maternity and family leave policies on employers is very limited. Some information on employers' experiences with PFL programs comes from surveys and in-depth interviews with selected firms from California and New Jersey, where PFL programs are funded through employee payroll contributions. In a series of reports and books, Eileen Appelbaum and Ruth Milkman report the results from California (Appelbaum and Milkman, 2011a,b; Milkman and Appelbaum, 2013). Their survey included about 250 California firms in 2009 and 2010, and they conducted in-depth interviews at 20 firms. Most firms (approximately 90 percent) report that CA-PFL had either a positive or neutral effect on employee productivity, morale, and costs. About two-thirds of the firms stated that they dealt with employee leave-taking by temporarily assigning work to others, while the remainder reported that they hired temporary replacements. In New Jersey, Ramirez (2012) and Lerner and Appelbaum (2014) report that surveyed businesses on average did not experience any impacts on profitability or employee productivity as a result of the PFL program. Moreover, there was no evidence that program administration was challenging or that employees resented their co-workers who took leave.

To date, there are no published peer-reviewed studies that have examined the impacts of leave programs on employers by comparing outcomes before and after the implementation of a program. A recent report prepared for the U.S. Department of Labor (Bartel et al., 2016) attempts such an analysis, using a survey of small and medium-sized businesses in the food services and manufacturing sectors in Rhode Island, Connecticut, and Massachusetts that was conducted in December 2013 (just before Rhode Island's PFL program went into effect) and in January and Februrary 2015 (one year after the law went into effect). Comparing Rhode Island employers pre- and post-law to Massachusetts and Connecticut employers over the same time period, the study found no evidence of significant impacts of the law on outcomes such as turnover rates or employee productivity. However, the sample sizes were 
small, limiting the conclusions that could be drawn from this analysis.

Another report prepared for the California Employment Development Department (EDD) (Bedard and Rossin-Slater, 2016) uses administrative data on nearly all California employers that ever existed between January 2000 and December 2014. They estimate panel data models with employer fixed effects, studying within-employer changes in outcomes as a function of changes in employee leave-taking rates. The results show no evidence that firm turnover or wage costs change when leave-taking rates rise - in fact, the average firm has a lower per-worker wage bill and a lower turnover rate today than it did before CA-PFL was introduced.

In sum, the current evidence suggests that employers are minimally affected by existing state-level PFL programs. However, more research needs to be conducted to understand the impacts of leave policies on employer outcomes, and to examine heterogeneity in these impacts across firms in different industries and of different sizes.

\section{Conclusion}

Maternity and family leave polices play an important role in helping working parentsespecially mothers - navigate the challenges of balancing job and family responsibilities upon the arrival of a new child. This review of the existing research provides insights into key questions regarding the take-up of leave, impacts on women's labor market experiences, consequences for child well-being, and effects on employers. The current evidence demonstrates that the introduction of new leave programs and extensions of existing programs increase leave-taking rates among parents. Leave policies that are less than one year in length can increase labor supply among women immediately after childbirth as well as several years later; longer leaves can have negative consequences on women's careers. Moreover, while extensions in existing paid leave programs have no impacts on child welfare, the introduction of short programs can improve infant health and children's long-run outcomes like education and earnings. With regard to employers, the current research finds little evidence of adverse 
impacts on self-reported productivity, employee morale, turnover rates or the total wage bill.

Yet important questions about these policies remain and serve as fertile grounds for future research. While most of the literature on the long-term impacts on child outcomes has focused on programs outside the U.S., much less is known about the possible consequences on long-run child welfare of the short PFL programs that have been introduced in several U.S. states. These programs operate in a very different policy setting than most programs in other countries (e.g., unlike in other countries such as Sweden, there is no universal childcare or health insurance in the U.S.), and are therefore likely to have distinct consequences on children. Research on this question could also provide insights into the determinants of human capital formation.

The existing research on employers is also limited; we know very little about how maternity and family leave policies may impact businesses, who often worry about being burdened with extra costs resulting from dealing with employee leave-taking. Understanding the possible effects of leave policies on employers is essential for informing any cost-benefit analysis.

Lastly, although leaves taken to care for new children are most common, some family leave programs also allow workers to take leave to care for ill family members. There is almost no existing research on the consequences of these policies for either caregivers or the ill family members who benefit from them.

\section{References}

Addati, L., N. Cassirer, and K. Gilchrist (2014). Maternity and paternity at work: Law and practice across the world. International Labour Office.

Aizer, A., L. Stroud, and S. Buka (2016). Maternal stress and child well-being: Evidence from siblings. Journal of Human Resources. Forthcoming.

Almqvist, A. L. and A. Z. Duvander (2014). Changes in gender equality? Swedish fathers' parental leave, division of childcare and housework1. Journal of Family Studies 20(1), $19-27$.

Anderson, D. J., M. Binder, and K. Krause (2002). The motherhood wage penalty: Which mothers pay it and why? The American Economic Review 92(2), 354-358. 
Appelbaum, E. and R. Milkman (2011a). Leaves That Pay: Employer and Worker Experiences with Paid Family Leave in California. Technical report.

Appelbaum, E. and R. Milkman (2011b). Paid Family Leave Pays Off in California. Harvard Business Review.

Baker, M. and K. Milligan (2008a). How Does Job-Protected Maternity Leave Affect Mothers' Employment? Journal of Labor Economics 26(4), 655-691.

Baker, M. and K. Milligan (2008b). Maternal employment, breastfeeding, and health: Evidence from maternity leave mandates. Journal of Health Economics 27(4), 871-887.

Baker, M. and K. Milligan (2010). Evidence from Maternity Leave Expansions of the Impact of Maternal Care on Early Child Development. Journal of Human Resources 45 (1), 1-32.

Baker, M. and K. Milligan (2015). Maternity leave and children's cognitive and behavioral development. Journal of Population Economics 28(2), 373-391.

Bartel, A., M. Rossin-Slater, C. Ruhm, J. Stearns, and J. Waldfogel (2015). Paid family leave, fathers' leave-taking, and leave-sharing in dual-earner households. Working Paper 21747, National Bureau of Economic Research.

Bartel, A., M. Rossin-Slater, C. Ruhm, and J. Waldfogel (2016). Assessing rhode island's temporary caregiver insurance act: Insights form a survey of employers. Report, U.S. Department of Labor, Chief Evaluation Office.

Baum, C. L. (2003). The Effects of Maternity Leave Legislation on Mothers' Labor Supply after Childbirth. Southern Economic Journal 69(694), 772-799.

Baum, C. L. and C. J. Ruhm (2016, apr). The Effects of Paid Family Leave in California on Labor Market Outcomes. Journal of Policy Analysis and Management 35(2), 333-356.

Bedard, K. and M. Rossin-Slater (2016). The economic and social impacts of paid family leave in california: Report for the california employment development department. Technical report. Prepared for the California Employment Development Department (Agreement No. M6102380).

Bergemann, A. and R. T. Riphahn (2015). Maternal Employment Effects of Paid Parental Leave (IZA DP No. 9073).

Black, S. E., P. J. Devereux, and K. G. Salvanes (2016). Does grief transfer across generations? bereavements during pregnancy and child outcomes. American Economic Journal: Applied Economics 8(1).

Blau, F. and L. Kahn (2000). Gender differences in pay. Journal of Economic Perspectives $14(4), 75-99$.

Bünning, M. (2015). What Happens after the 'Daddy Months'? Fathers' Involvement in Paid Work, Childcare, and Housework after Taking Parental Leave in Germany. European Sociological Review 0(0), 1-11. 
Bunning, M. and M. Pollmann-Schult (2016, apr). Family policies and fathers working hours: cross-national differences in the paternal labour supply. Work, Employment $\varepsilon^{3}$ Society 30(2), 256-274.

Carneiro, P., K. Loken, and K. Salvanes (2015). A Flying Start: Maternity Leave Benefits and Long Run Outcomes of Children. Journal of Political Economy 123(2), 365-412.

Colombo, F., A. Llena-Nozal, J. Mercier, and F. Tjadens (2011). Help wanted? providing and paying for long-term care. Report, Organization for Economic Cooperation and Development.

Cools, S., J. H. Fiva, and L. J. Kirkebøen (2015). Causal Effects of Paternity Leave on Children and Parents. Scandinavian Journal of Economics 117(3), 801-828.

Currie, J. and M. Rossin-Slater (2013). Weathering the storm: Hurricanes and birth outcomes. Journal of Health Economics 32(3), 487 - 503.

Dahl, G. B., K. V. Løken, and M. Mogstad (2014). Peer effects in program participation. The American Economic Review 104 (7), 2049-2074.

Dahl, G. B., K. V. Løken, M. Mogstad, and K. V. Salvanes (2016). What is the case for paid maternity leave? Review of Economics and Statistics. Forthcoming.

Danzer, N. and V. Lavy (2016). Paid parental leave and children's schooling outcomes. Economic Journal. Forthcoming.

Das, T. and S. W. Polachek (2015). Unanticipated Effects of California'S Paid Family Leave Program. Contemporary Economic Policy 33(4), 619-635.

DiCamillo, M. and M. Field (2015). Just 36\% of voters aware of state's paid family leave program. Technical report, Field Research Corporation.

Dustmann, C. and U. Schönberg (2012). Expansions in maternity leave coverage and children's long-term outcomes. American Economic Journal: Applied Economics 4(3), 190224.

Dustmann, C. and U. Schönberg (2012). Expansions in maternity leave coverage and children's long-term outcomes. American Economic Journal: Applied Economics 4(3), 190224.

Ekberg, J., R. Eriksson, and G. Friebel (2013). Parental leave - a policy evaluation of the swedish "daddy-month" reform. Journal of Public Economics 97, 131-143.

Fass, S. (2009). Paid Leave in the States A Critical Support for Low-wage Workers and Their Families. Technical report.

Gault, B., H. Hartmann, A. Hegewisch, J. Milli, and L. Reichlin (2014, March). Paid parental leave in the united states: What the data tell us about access, usage, and economic and health benefits. Report, Institute for Women's Policy Research. 
Gregg, P., M. Gutiérrez-Domènech, and J. Waldfogel (2007). The Employment of Married Mothers in Great Britain, 1974-2000. Economica 74(296), 842-864.

Han, W.-J., C. Ruhm, and J. Waldfogel (2009). Parental Leave Policies and Parents' Employment and Leave- Taking. Journal of Policy Analysis Management 28(1), 29-54.

Han, W. J. and J. Waldfogel (2003). Parental leave: The impact of recent legislation on parents' leave taking. Demography 40(1), 191-200.

Heymann, J., A. Raub, and A. Earle (2011). Creating and using new data sources to analyze the relationship between social policy and global health: The case of maternal leave. Public Health Reports 126(3), 127-134.

Huang, R. and M. Yang (2015). Paid maternity leave and breastfeeding practice before and after California's implementation of the nation's first paid family leave program. Economics 63 Human Biology 16, 45-59.

Huerta, C., W. Adema, J. Baxter, J. Han, M. Lausten, R. Lee, and J. Waldfogel (2013). Fathers' Leave, Fathers' Involvement and Child Development: Are they related? Evidence from four OECD countries.

Klerman, J. A., K. Daley, and A. Pozniak (2012). Family and medical leave in 2012: Technical report. Technical report, Abt Associates Inc. Prepared for the U.S. Department of Labor (Contract No. GS10FOO86K).

Klerman, J. A. and A. Leibowitz (1994). The Work-Employment Distinction Among New Mothers. The Journal of Human Resources 29(2), 277-303.

Klerman, J. A. and A. Leibowitz (1997). Labor supply effects of state maternity leave legislation. In R. Blau, FD and Ehrenberg (Ed.), Gender and Family Issues in the Workplace, pp. 65-91.

Kleven, H. J., C. Landais, and J. E. Søgaard (2016). Children and Gender Inequality: Evidence from Denmark. London School of Economics, unpublished manuscript.

Kluve, J., M. Tamm, J. Kluve, and M. Tamm (2013). Parental leave regulations, mothers' labor force attachment and fathers' childcare involvement: evidence from a natural experiment. Journal of Population Economics 26(3), 983-1005.

Lalive, R. and J. Zweimüller (2009). How Does Parental Leave Affect Fertility and Return to Work? Evidence from Two Natural Experiments. The Quarterly Journal of Economics 124(3), 1363-1402.

Lequien, L. (2012). The Impact of Parental Leave Duration on Later Wages. Annals of Economics and Statistics 107/108(July/December), 267-285.

Lerner, S. and E. Appelbaum (2014). Business As Usual: New Jersey Employers' Experiences with Family Leave Insurance. 
Liu, Q. and O. Skans (2010). The Duration of Paid Parental Leave and Children 's Scholastic Performance Children's Scholastic Performance. The B.E. Journal of Economic Analysis \& Policy 10(1), 1-33.

Lundberg, S. and E. Rose (2000). Parenthood and the earnings of married men and women. Labour Economics 7(6), 689-710.

Milkman, R. and E. Appelbaum (2013). Unfinished Business: Paid Family Leave in California and the Future of U.S. Work-Family Policy. ILR Press.

Nepomnyaschy, L. and J. Waldfogel (2007, nov). Paternity leave and fathers' involvement with their young children. Community, Work \& Family 10(4), 427-453.

Patnaik, A. (2016). Reserving time for daddy: The short and long-run consequences of fathers' quotas. Unpublished manuscript.

Persson, P. and M. Rossin-Slater (2016). Family ruptures, stress, and the mental health of the next generation. American Economic Review. Forthcoming.

Ramirez, M. (2012). The Impact of Paid Family Leave on New Jersey Businesses. Technical report, Bloustein School of Planning and Public Policy.

Rasmussen, A. W. (2010). Increasing the length of parents' birth-related leave: The effect on children's long-term educational outcomes. Labour Economics 17(1), 91-100.

Rege, M. and I. F. Solli (2013). The Impact of Paternity Leave on Fathers' Future Earnings. Demography 50(6), 2255-2277.

Rossin, M. (2011). The effects of maternity leave on children's birth and infant health outcomes in the united states. Journal of health Economics 30(2), 221-239.

Rossin-Slater, M., C. J. Ruhm, and J. Waldfogel (2013). The effects of california's paid family leave program on mothers' leave-taking and subsequent labor market outcomes. Journal of Policy Analysis and Management 32(2), 224-245.

Ruhm, C. (2000). Parental Leave and Child Health. Journal of Health Economics 19(6), 931-960.

Ruhm, C. J. (1997). Policy watch - The Family and Medical Leave Act. Journal of Economic Perspectives 11(3), 175-186.

Ruhm, C. J. (1998). The economic consequences of parental leave mandates: lessons from europe. Quarterly Journal of Economics 113(1), 285-317.

Schönberg, U. and J. Ludsteck (2014). Expansions in maternity leave coverage and mothersâ labor market outcomes after childbirth. Journal of Labor Economics 32 (3), 469-505.

Schönberg, U. and J. Ludsteck (2014). Expansions in Maternity Leave Coverage and Mothers' Labor Market Outcomes after Childbirth. Journal of Labor Economics 32 (3), 469-505. 
Schott, W. (2012, feb). Going Back Part-time: Family Leave Legislation and Women's Return to Work. Population research and policy review 31(1), 1-30.

Stearns, J. (2015). The effects of paid maternity leave: Evidence from Temporary Disability Insurance. Journal of Health Economics 43, 85-102.

Stearns, J. (2016). Long-run effects of maternity leave: Evidence from britain. UC Santa Barbara, unpublished manuscript.

Tanaka, S. (2005). Parental Leave and Child Health Across OECD Countries. The Economic Journal 115(501), F7-F28.

Tanaka, S. and J. Waldfogel (2007). Effects of Parental Leave and Work Hours on Fathers' Involvement with Their Babies. Community, Work and Family 8803(May), 409-426.

Trzcinski, E. and W. T. Alpert (1994). Pregnancy and parental leave benefits in the united states and canada: Judicial decisions and legislation. Journal of Human Resources, 535554 .

Waldfogel, J. (1998). The family gap for young women in the united states and britain: Can maternity leave make a difference? Journal of labor economics 16(3), 505-545.

Waldfogel, J. (1999). The impact of the Family and Medical Leave Act. Journal of Policy Analysis and Management 18(2), 281-302.

Washbrook, E., C. J. Ruhm, J. Waldfogel, and W.-J. Han (2011). Public Policies, Women's Employment after Childbearing, and Child Well-Being. B.E. Journal of Economic Analysis \& Policy 11(1). 
Figure 1: Weeks of Paid Family Leave by State

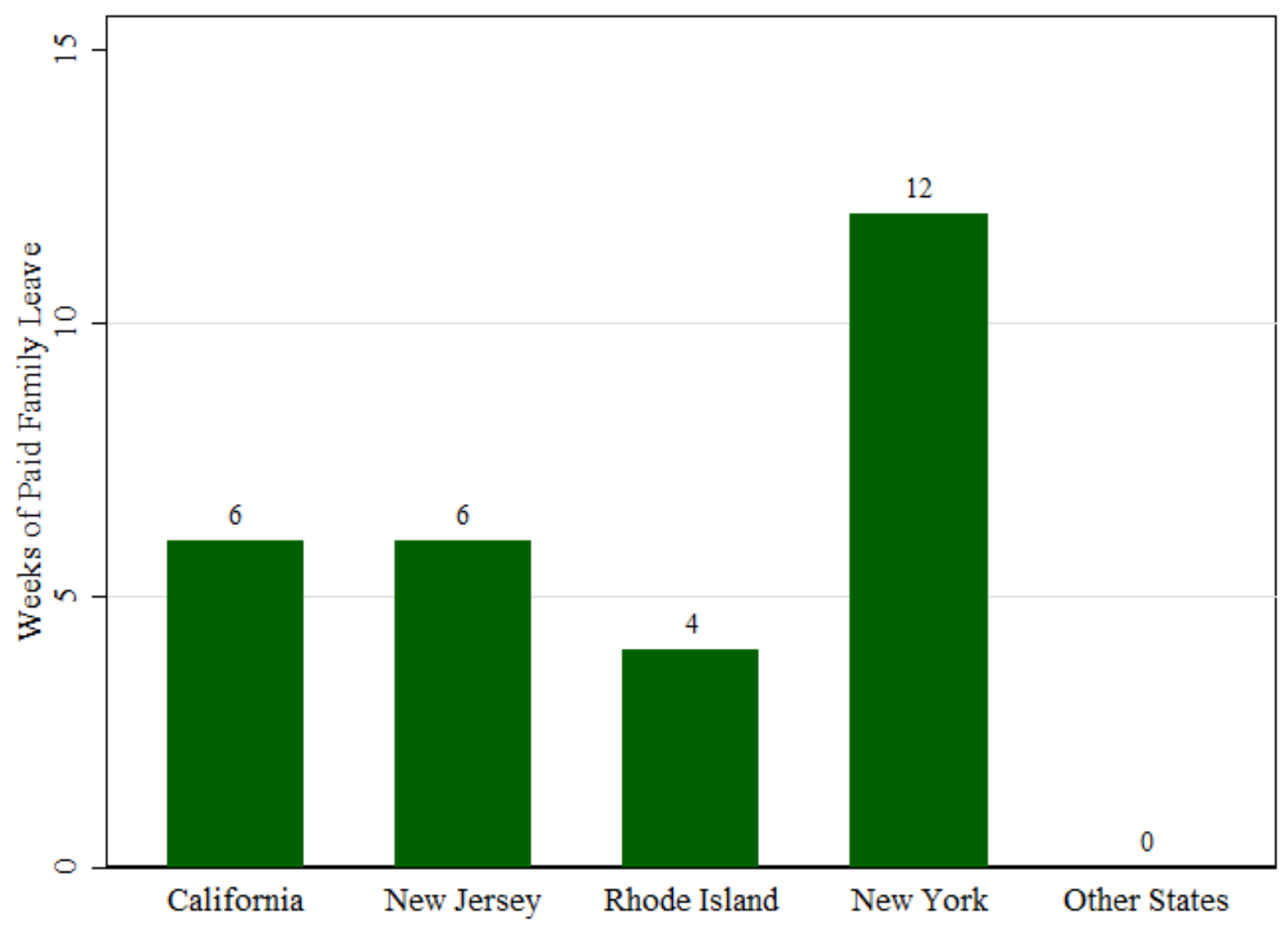

\section{Sources:}

CA (implemented in 2004): http://www.edd.ca.gov/Disability/About_PFL.htm

NJ (implemented in 2008): http://lwd.dol.state.nj.us/labor/fli/fliindex.html

RI (implemented in 2014): http://www.dlt.ri.gov/tdi/

NY (will be implemented in 2018): https://www.ny.gov/programs/paid-family-leave-strong-families-strongny. Note that the NY policy will be phased in gradually - 8 weeks of PFL will be available in 2018, and 12 weeks by 2021 . 
Figure 2: Average Weekly Paid Family Leave Benefit by State, 2015

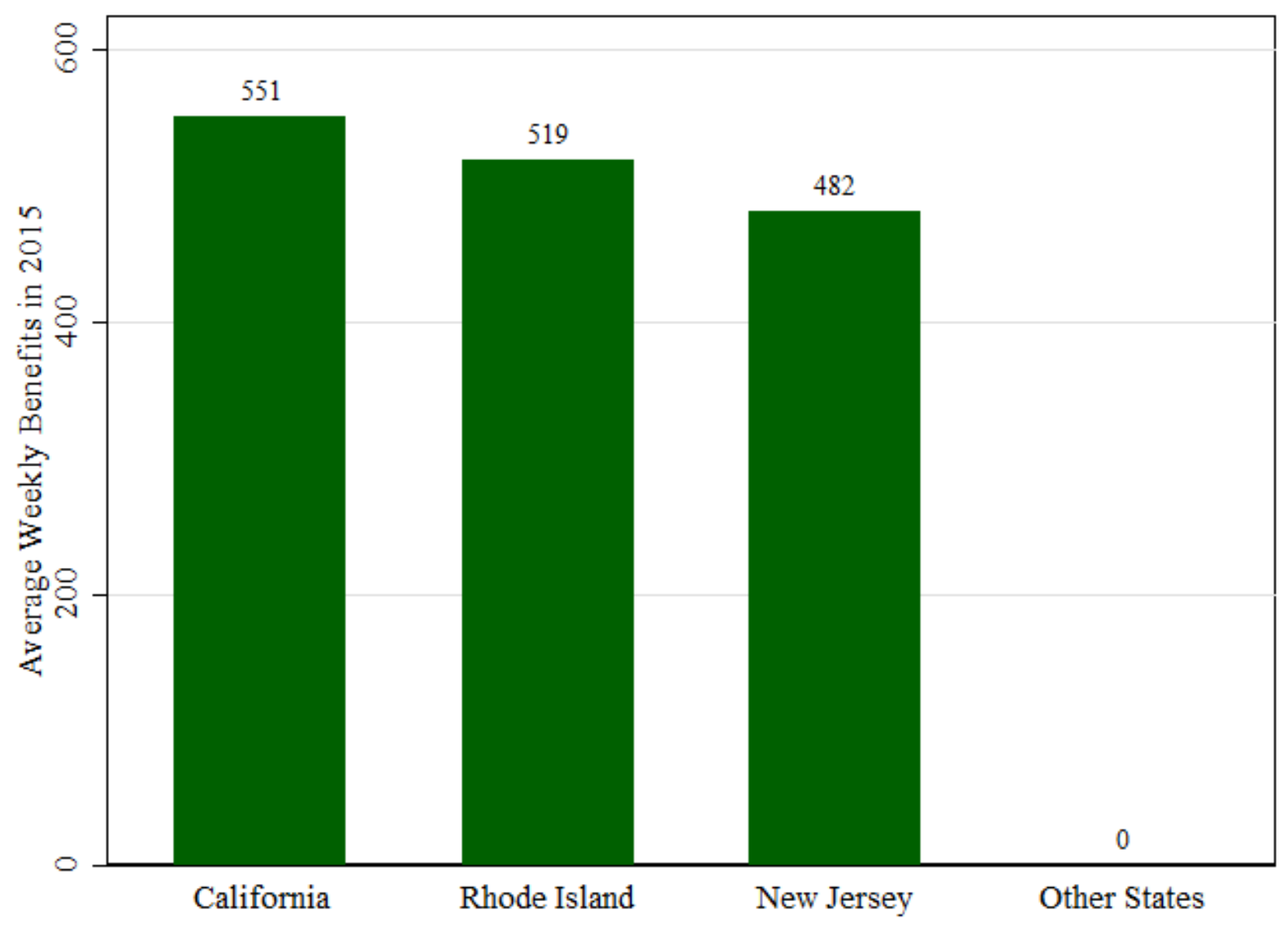

Sources:

CA: State of California Employment Development Department, State Disability Insurance - Quick Statistics, http://www.edd.ca.gov/about_edd/pdf/qspfl_Avg_WBA.pdf

NJ: State of New Jersey, Department of Labor and Workforce Development, FLI - Program Statistics: 2015 Monthly Statistics, http://lwd.dol.state.nj.us/labor/fli/content/2015_monthly_report_fli.html. Average benefit for New Jersey calculated by dividing total 2015 benefit payments by number of eligible claims and number of weeks of benefits available.

RI: Rhode Island Department of Labor and Training, TDI Annual Update: January - December 2015, http://www.dlt.ri.gov/lmi/pdf/tdi/2015.pdf 